\title{
Homeopathy for Covid-19 in Primary Care: A structured summary of a study protocol for a randomized controlled trial
}

Ubiratan Cardinalli Adler ${ }^{1^{*}} \mathbb{D}$, Maristela Schiabel Adler ${ }^{1}$, Livia Mitchiguian Hotta², Ana Elisa Madureira Padula ${ }^{3}$, Amarilys de Toledo Cesar ${ }^{4}$, José Nelson Martins Diniz ${ }^{5}$, Crislaine Aparecida Antonio Mestre ${ }^{6}$, Katia Regina Spiller ${ }^{7}$, Lidiamara Soares ${ }^{7}$, Helen de Freitas Santos ${ }^{8}$ and Edson Zangiacomi Martinez ${ }^{9}$

\section{Abstract}

Objectives: To investigate the effectiveness and safety of homeopathic medicine Natrum muriaticum (LM2) for mild cases of COVID-19 in Primary Health Care.

Trial design: A randomized, two-armed (1:1), parallel, placebo-controlled, double-blind, clinical trial is being performed to test the following hypotheses:

- Ho: homeopathic medicines = placebo (null hypothesis) vs.

- H1: homeopathic medicines ₹ placebo (alternative hypothesis) for mild cases of COVID-19 in Primary Care.

Participants: Setting: Primary Care of São Carlos - São Paulo - Brazil.

One hundred participants aged 18 years or older, with Influenza-like symptoms and a positive RT-PCR for SARS-CoV2. Willingness to give informed consent and to comply with the study procedures is also required. Exclusion criterium: severe acute respiratory syndrome.

\section{Intervention and comparator:}

- Homeopathy: 1 globule of Natrum muriaticum LM2 diluted in $20 \mathrm{~mL}$ of alcohol 30\% and dispensed in a $30 \mathrm{ml}$ bottle.

- Placebo: $20 \mathrm{~mL}$ of alcohol 30\% dispensed in a $30 \mathrm{ml}$ bottle.

Posology: one drop taken orally every 4 hours ( 6 doses/day) while there is fever, cough, tiredness, or pain (headache, sore throat, muscle aches, chest pain, etc.) followed by one drop every 6 hours ( 4 doses/day) until the fourteenth day of use. The bottle of study medication should be submitted to 10 vigorous shakes (succussions) before each dose. Posology may be changed by telemedicine, with no break in blinding.

Study medication should be maintained during home isolation. According to the Primary Care protocol, the home (Continued on next page)

\footnotetext{
* Correspondence: ubiratanadler@ufscar.br

${ }^{1}$ Medicine Department, Universidade Federal de São Carlos, Rodovia

Washington Luiz, Km 235, São Carlos, SP, Brasil 13565-905

Full list of author information is available at the end of the article
}

(c) The Author(s). 2021 Open Access This article is licensed under a Creative Commons Attribution 4.0 International License, which permits use, sharing, adaptation, distribution and reproduction in any medium or format, as long as you give appropriate credit to the original author(s) and the source, provide a link to the Creative Commons licence, and indicate if changes were made. The images or other third party material in this article are included in the article's Creative Commons licence, unless indicated otherwise in a credit line to the material. If material is not included in the article's Creative Commons licence and your intended use is not permitted by statutory regulation or exceeds the permitted use, you will need to obtain permission directly from the copyright holder. To view a copy of this licence, visit http://creativecommons.org/licenses/by/4.0/ The Creative Commons Public Domain Dedication waiver (http://creativecommons.org/publicdomain/zero/1.0/) applies to the data made available in this article, unless otherwise stated in a credit line to the data. 
(Continued from previous page)

isolation period lasts until the $10^{\text {th }}$ day after the appearance of the first symptom, or up to 72 hours without symptoms.

Main outcomes: The primary endpoint will be time to recovery, defined as the number of days elapsed before all COVID-19 Influenza-like symptoms are recorded as mild or absent during home isolation period. Secondary measures are recovery time for each COVID-19 symptom; score of the scale created for the study (COVID-Simile Scale); medicines used during follow-up; number of days of follow-up; number of visits to emergency services; number of hospitalizations; other symptoms and Adverse Events during home isolation period.

Randomisation: The study Statistician generated a block randomization list, using a 1:1 ratio of the two groups (denoted as A and B) and a web-based tool (http://www.random.org/lists).

Blinding (masking): The clinical investigators, the statistician, the Primary Care teams, the study collaborators, and the participants will remain blinded from the identity of the two treatment groups until the end of the study.

Numbers to be randomised (sample size): One hundred participants are planned to be randomized (1:1) to placebo (50) or homeopathy (50).

Trial Status: Protocol version/date May 21, 2020. Recruitment is ongoing. First participant was recruited/included on June 29,2020. Due to recruitment adaptations to Primary Care changes, the authors anticipate the trial will finish recruiting on April 10, 2021.

Trial registration: COVID-Simile Study was registered at the University Hospital Medical Information Network (UMIN - https://www.umin.ac.jp/ctr/index.htm) on June $1^{\text {st }}, 2020$, and the trial start date was June 15, 2020. Unique ID: UMIN000040602.

Full protocol: The full protocol is attached as an additional file, accessible from the Trials website (Additional file 1). In the interest in expediting dissemination of this material, the familiar formatting has been eliminated; this Letter serves as a summary of the key elements of the full protocol.

Keywords: COVID-19, Homeopathy, Unified Health System, Primary Care, Telemedicine, Randomized Controlled Trial protocol

\section{Supplementary Information}

The online version contains supplementary material available at https://doi. org/10.1186/s13063-021-05071-5.

Additional file 1.

\section{Acknowledgements}

Health Secretary of São Carlos, Mr. Marcos Palermo, for the trust. Primary Care Unities teams of São Carlos, for their collaboration in times of multiple crises. HN-Cristiano Pharmacy, São Paulo, for kindly providing the study medication. Ms. Cláudia Rejane Zangotti da Costa, Administrative Assistant at School Health Unit/UFSCar (USE), for coordinating medication and Informed Consent logistics. Thales Schiabel Adler, for reviewing the manuscript and adding relevant suggestions to the text.

\section{Authors' contributions}

All authors certify that they have participated sufficiently in the work to take public responsibility for the content, including participation in the concept (UCA), design (UCA, MSA, LMH, AEP, ATC, JNMD, CAAM, KRS, LS, HFS, EZM), analysis (EMZ), writing (UCA), or revision of the manuscript (UCA, MSA). The author(s) read and approved the final manuscript.

\section{Funding}

This research did not receive any specific grant from funding agencies in the public, commercial, or not-for-profit sectors. Study medication has been kindly provided by HN-Cristiano Homeopatia - Sao Paulo, SP, Brazil. HNCristiano did not participate in the design of the study and collection, analysis, and interpretation of data and in writing the manuscript, except for the donation of study medication.

\section{Availability of data and materials}

The data will be available from the author on reasonable request Ubiratan Cardinalli Adler, M. D, Ph.D.

Universidade Federal de São Carlos, Medicine Department

Rodovia Washington Luiz, Km 235, São Carlos, SP, Brasil - 13565-905

Tel. +55 16 3351-9420

ubiratanadler@ufscar.br

\section{Ethics approval and consent to participate}

COVID-Simile study Presentation Certificate for Ethical Appreciation (CAAE) number is 30638220.0.0000.0008, which was approved by the Brazilian National Research Ethics Commission (CONEP) on May 31 $1^{\text {st }}, 2020$ (report \# 4.059.759)

Ethical approval is available at:

https://plataformabrasil.saude.gov.br/login.jsf;jsessionid=1D49B939CC1FB72 79B4E8A7117C2C664.server-plataformabrasil-srvjpdf130 [Portuguese]. Please click on "Confirmar Aprovação pelo CAAE ou Parecer" (Confirm Approval by CAAE or report \#. The system only shows approved protocols. Informed Consent $(\mathrm{IC})$ is presented and explained during recruitment by telemedicine. Two counterparts of the IC (pre-signed by the principal investigator) are sent to the participant's home address, through a delivery company, which returns the signed IC to the study centre, completing the Inclusion process.

\section{Consent for publication}

Not applicable.

\section{Competing interests}

The authors declare that they have no competing interests.

Cesar AT is co-owner of HN-Cristiano Homeopatia, the pharmacy that has donated the study medication, however, Natrum muriaticum has been in use for over 150 years and is not patentable. 


\section{Author details}

'Medicine Department, Universidade Federal de São Carlos, Rodovia Washington Luiz, Km 235, São Carlos, SP, Brasil 13565-905. ${ }^{2}$ Centro Municipal de Práticas Integrativas e Complementares em Saúde CEMPICS, Rua Joaquim Miranda, 471, Guarulhos, SP 07023-051, Brasil. ${ }^{3}$ Universidade Presbiteriana Mackenzie, R. Piauí, 181, São Paulo, SP 01241-001, Brasil. ${ }^{4}$ Instituto HN-Cristiano, Rua Dr. Cesar 212, São Paulo, SP 02013-001, Brasil.

${ }^{5}$ Universidade Federal de São Carlos, School Health Unit (USE), Rodovia Washington Luiz, Km 235, São Carlos, SP, Brasil 13565-905. 'São Carlos' Health Surveillance, R. Conde do Pinhal, 2161 -, São Carlos, SP 13560-648, Brasil. 'São Carlos' Epidemiological Surveillance, R. Conde do Pinhal, 2161, São Carlos, SP 13560-648, Brasil. " Instituto Federal de Educação Ciência e Tecnologia de São Paulo, R. Pedro Cavalo, 709, Birigui, SP 16201-407, Brasil. ${ }^{9}$ Social Medicine Department, Universidade de São Paulo - Faculdade de Medicina de Ribeirão Preto, Av. Bandeirantes, 3900, Ribeirão Preto, SP, Brasil 14049-900

Received: 19 January 2021 Accepted: 24 January 2021

Published online: 01 February 2021

\section{Publisher's Note}

Springer Nature remains neutral with regard to jurisdictional claims in published maps and institutional affiliations.

Ready to submit your research? Choose BMC and benefit from:

- fast, convenient online submission

- thorough peer review by experienced researchers in your field

- rapid publication on acceptance

- support for research data, including large and complex data types

- gold Open Access which fosters wider collaboration and increased citations

- maximum visibility for your research: over $100 \mathrm{M}$ website views per year

At BMC, research is always in progress.

Learn more biomedcentral.com/submissions 